\title{
MENJADI MANUSIA INDONESIA YANG OTENTIK: BELAJAR DARI HANS KUNG
}

\author{
Andreas M. Putra \\ Konsultan Bisnis dan Aktivis Lingkungan
}

\begin{abstract}
Globalization has a significant impact on the dynamics of human life. The activities and creativities of individuals in society are facilitated. Everyone's knowledge and relations are increasingly widespread. Humans are becoming increasingly competent in various dimensions: space and time. The cool breeze brought by modernity refreshes the external needs of personal and communal life. But the cool breeze of modernity inevitably lulls the deepest elements of life. The idea of humans must be treated humanly, is experiencing lameness. This dimension is blurred because it is rarely criticized as the societies, both globally (world) and locally (Indonesia), are lulled by the pleasures of modernity. In the light of Hans Kung's thought, the perspectives in this discourse affirm the commitment to realize human authenticity in general, in a global context, and its implementation into the local domain, our Indonesian-hood. The ideas presented in this thesis frame -more or less- a fundamental problem experienced by modern humans and the possibility of its anticipation in the future so that the hope of realizing authentic human beings as outward and spiritual in nature, will not be lost due to erosion and carried away by globalization.
\end{abstract}

KEYWORDS: globalization, fundamental demands, authentication, commitment, implementation, spirit of Pancasila.

ABSTRAK: Globalisasi membawa dampak signifikan dalam dinamika hidup manusia. Aktivitas dan kreativitas individu dalam masyarakat dipermudah. Wawasan dan relasi setiap orang semakin meluas. Manusia menjadi semakin kompeten dalam berbagai dimensi: ruang dan waktu. Angin sejuk yang dibawa modernitas menyegarkan kembali kebutuhan- 
kebutuhan luaran hidup pribadi dan kelompok. Namun sejuknya angin modernitas tak pelak meninabobokan unsur terdalam kehidupan. Manusia harus diperlakukan secara manusia, mengalami kepincangan. Dimensi ini menjadi kabur lantaran jarang dikritisi karena masyarakat, baik secara global (dunia) maupun lokal (Indonesia) terlena oleh nikmatnya tawaran-tawaran modernitas. Dalam terang pemikiran Hans Kung, perspektif-perspektif dalam diskursus ini memberi penegasan pada komitmen mewujudkan otentisasi manusia secara umum dalam konteks global dan implementasi ke ranah lokal, keindonesiaan kita. Ide-ide yang tersaji di dalam tesis ini membingkai--kurang lebih--apa yang menjadi persoalan fundamental yang dialami manusia-manusia modern dan kemungkinan antisipasi ke depannya sehingga harapan merealisasikan manusia-manusia yang otentik sebagaimana hakikat lahiriah dan spiritual, tidak hilang tergerus dan terbawa arus globalisasi.

KATA-KATA KUNCI: globalisasi, tuntutan fundamental, otentisasi, komitmen, implementasi, semangat Pancasila.

\section{Pengantar}

Di tengah majunya peradaban, dengan segala model dan tawaran instan akibat ekspansi teknologi, ada satu kekhawatiran fundamental yang sebetulnya disadari namun jarang dikritisi lebih lanjut. Kecenderungan menyimpulkan bahwa masyarakat global sedang menikmati arus globalisasi terasa lebih menarik ketimbang menelusuri nilai-nilai mendasar yang sedang pincang. Betul, bahwa arus kemajuan ilmu pengetahuan dan teknologi memodernisasi kehidupan manusia dan mobilisasinya, tetapi jangan sampai lupa bahwa globalisasi menyisakan ruang gelap pada ranah yang paling inti sebagai tuntutan dasariah yaitu memanusiakan masyarakat. Terutama di tengah peradaban yang makin liar kiblatnya, kekalutan fundamental seperti ini terdengar sayup-sayup meskipun secara faktual, menggelegar suaranya.

Kenyataan yang tak terbantahkan adalah dunia kita, juga dalam konteks keindonesiaan, sedang mengalami krisis fundamental: krisis 
ekonomi, ekologi dan politik yang mengglobal. Minimnya nilai rasa untuk kesejahteraan bersama tampaknya telah merata. Ditambah persoalan-persoalan yang tak terpecahkan, pengangguran, kemiskinan, kelaparan, penghancuran, konflik sosial, ras dan etnik serta korupsi terorganisir menambah daftar kegamangan sisi fundamental. Padahal semua itu, jika dibenahi, akan bermuara pada terciptanya manusia yang otentik. Atau dengan kata lain, jika persoalan-persoalan dasariah di atas diatasi maka secara tidak langsung, perwujudan usaha pemanusiaan terkonkretisasi.

Melihat beragam kecemasan fundamental baik global maupun lokal (Indonesia) yang sedang terjadi di era modern, penulis menyuarakan beberapa poin penting untuk menemukan visi baru memperjuangkan kehidupan manusia yang lebih otentik karena otentisitas adalah basis dari seluruh pergulatan manusia sejak lahir, bertumbuh (dewasa) dan mati. Maka ide yang tersaji dalam tulisan ini merupakan refleksi kritis sekaligus pedoman untuk berpikir secara baru, bagaimana seorang manusia mesti diperlakukan terutama di tengah arus modernisasi yang merambah ke segala lingkup kehidupan, ruang dan waktu, tanpa kompromi dan bagaimana menerjemahkan pemikiran Kung (komitmen-komitmen fundamental) untuk diimplementasikan dalam konteks kekinian Indonesia yang pluralis.

Melalui metode hermeneutik intra-teks dan studi data-data sosial, penulis mencoba menyingkap kemungkinan-kemungkinan baru menjawab pertanyaan refleksi di atas: usaha memanusiakan manusia dan implementasinya ke dalam konteks Indonesia yang plural sehingga pada akhirnya keotentikan bisa terus dirawat selaras hakikat lahiriah dan spiritual manusia.

\section{Dasar Pemikiran}

Pertanyaan fundamen, siapa itu manusia, akan menjadi titik acuan refleksi kritis yang mau tidak mau, perlu digemakan secara kontinuitas sepanjang permenungan hidup manusia sendiri. Sebagai makhluk 
multitafsir dan multidimensi, manusia terlalu kompleks untuk dirumuskan. Sejatinya tidak ada ilmu yang sungguh mampu menjelaskan siapa manusia secara tuntas dan lengkap. Meski beragam usaha dan disiplin ilmu belum mampu merumuskan kompleksitas diri manusia, ada satu hal yang tak terelakkan dan tak dapat dibantah, yaitu hidupnya tertuju pada keotentikan. Keotentikan dalam konteks ini adalah dalam ruang lingkup apapun, dalam situasi apapun dan di mana pun, manusia mesti diperlakukan layaknya seorang manusia. Tidak di luar itu, di luar hakikat aslinya dan habitus asalinya.

Secara historis, manusia dipandang sebagai ciptaan paling sempurna. Ia merupakan suatu totalitas, bukan gabungan dari beberapa komponen. Terminologi seperti tubuh, jiwa dan roh tidak menunjuk kepada komponen-komponen, tetapi kepada aspek-aspek dari suatu keutuhan. Maka sudah selayaknya ia diperlakukan seturut hakikatnya. Dari sudut pandang lain manusia juga rekan kerja Allah di dunia yang diberi kepercayaan mengolah dan menata dunia menjadi teratur dan indah. Selayaknya, ia adalah rekan Sang Pencipta, maka setiap individu adalah rekan kerja kita. Maka kita pun dituntut memperlakukannya sebagai rekan, bukan musuh karena sama-sama sebagai rekan kerja Allah. Lebih persisnya, dalam diri setiap individu terpancar sifat-sifat Allah, yang perlu dihormati. Kamaluddin menjelaskan bahwa "manusia adalah makhluk Tuhan yang otonom, pribadi yang tersusun atas kesatuan harmonik jiwa raga dan eksis sebagai individu yang memasyarakat"1.

Manusia diciptakan oleh Tuhan namun manusia juga diberikan hak otonom untuk menjalani hidupnya. Dalam menjalani kehidupannya, manusia diberikan kebebasan untuk dapat menyelesaikan dan mengatasi permasalahan dalam hidupnya.

1 U.A. Kamaluddin, Filsafat Manusia: Sebuah Perbandingan antara Islam dan Barat (Bandung: CV Pustaka Setia, 2013), 5. 
Dalam konteks ini, memanusiakan manusia menjadi tuntutan fundamental yang tidak bisa diabaikan. Perlu realisasi. Kata lainnya, realisasi dari tuntutan fundamental adalah individu-individu harus melihat dan memperlakukan sesamanya sebagai manusia yang utuh. Paus Paulus VI menulis dalam Ensiklik Populorum Progressio, "Perkembangan sejati harus menyeluruh, artinya harus menguntungkan manusia seutuhnya dan seluruh umat manusia." Pembangunan sejati adalah pembangunan manusia seutuhnya. ${ }^{2}$

Hans Kung turut menyuarakan komitmen ini dalam suatu kesempatan konferensi etik global: "di hadapan seluruh umat manusia, keyakinan keagamaan dan etik, kami menuntut bahwa setiap manusia harus diperlakukan secara manusiawi."3 Artinya "setiap manusia tanpa melihat perbedaan jenis kelamin, ras, warna kulit, kemampuan fisik atau mental, bahasa, agama, pandangan politik, latar belakang sosial dan nasional memiliki martabat yang asasi dan tidak dapat diganggu gugat."4

Adalah sebuah komitmen yang pertama-tama harus disadari baik secara pribadi dan kelompok. Kemanusiaan secara urgen memerlukan reformasi individu dan sosial namun lebih urgennya juga butuh pembaruan ekologis dan spiritual. Manusia harus menjadi pemilik hak, harus menjadi tujuan, bukan sekadar sarana, tidak boleh menjadi objek komersialisasi dan industrialisasi dalam ekonomi, politik dan media, dalam lembaga-lembaga penelitian dan korporasi industrial. ${ }^{5}$

Atas konsensus ini, setiap orang mesti kembali kepada landasan prinsip yang terdapat dalam banyak tradisi keagamaan dan etika kemanusiaan selama ribuan tahun: apa yang tidak ingin orang lakukan kepadamu, jangan lakukan pada orang lain! Prinsip ini harus "menjadi norma yang tidak boleh diganggu gugat, berlaku universal bagi semua wilayah

\footnotetext{
2 Paus Paulus VI, Ensiklik Populorum Progressio (Roma, 26 Maret 1967), 9.

3 Hans Kung dan Karl-Josef Kuschel, Etika Global (Yogyakarta: Pustaka Pelajar, 1999), 19.

4 Ibid.

5 Ibid.
} 
kehidupan, keluarga dan komunitas, ras, bangsa dan agama-agama"6. Egoisme mesti ditolak, individuslistik, pemikiran kelas, rasisme atau seksisme perlu dihilangkan karena hanya akan menghalangi manusia untuk menjadi manusia secara otentik.

Gabriel Marcel menegaskan kembali bahwa tubuh manusia bukan subyek bukan pula obyek, melainkan pada waktu yang bersamaan, harus dikatakan bahwa tubuh adalah kedua-duanya. Marcel menjelaskan 'aku adalah tubuhku, tetapi secara serentak, dipandang dari segi lain, aku juga mempunyai tubuhku'. Semua ini merupakan cerminan cara beradanya tubuh yang khas sebagai penengah antara manusia dan dunianya. ${ }^{7}$

Sementara bagi Berger, kedirian manusia tidak terlepas dari lingkungannya. Dunia manusia adalah dunia yang harus dibentuk oleh aktivitas manusia. Hal ini tentu merupakan petunjuk yang sangat jelas bahwa hubungan manusia dengan lingkungannya bercirikan pada keterbukaan dunia (world-openness). Pemikiran Berger tentang manusia berada dalam pemahaman tentang kedirian manusia, yang tidak diandaikan atas asumsi yang mendasari kodratnya, tetapi diandaikan atas eksistensi yang dasar akan dunia. Manusia yang terdiri dari bagianbagian dan aspek-aspek yang begitu kaya. Manusia terdiri dari badan dan jiwa, yang masing-masing mempunyai kegiatan, kemampuan, dan gaya, serta perkembangannya sendiri. ${ }^{8}$

\section{Dunia dan Realitas Kita Kini}

Dunia dan manusia merupakan substansi-substansi yang tak terpisahkan. Dunia, dalam segala macam proses perubahannya, memerlukan manusia dengan kreativitasnya. Begitu juga manusia, dalam proses dan transformasi hidupnya, ia membutuhkan dunia tempat

\footnotetext{
6 Hans Kung dan Karl-Josef Kuschel, Etika Global, 20.

7 K. Bertens, Panorama Filsafat Modern (Jakarta: Gramedia, 1987), 59.

8 Whitehead, Jatidiri Manusia Berdasarkan Filsafat Organisme (Yogyakarta: Kanisius, 1996), 25.
} 
pengaktualisasian diri akan eksistensinya. Dunia dan realitas manusia masa kini adalah modernitas. Globalisasi sebagai mazhab hasil pergeseran rasionalitas manusia, dari yang primodial menjadi modern. Secara faktual, modernitas diakui memunculkan optimisme kemajuan manusia melalui penemuan sains dan teknologi, tetapi pada sisi lain ia tidak mampu menjawab problem-problem besar yang dihasilkan dari dampak kemajuan tersebut. Banyaknya bencana kemanusiaan memerlihatkan bahwa modernitas gagal membuat dunia semakin damai, aman dan sejahtera. Bahkan dari perspektif paling luhur, modernitas mengaburkan dimensi keberimanan seseorang. Keilahian menjadi dagangan murah dalam dunia yang makin sekuler. Tuhan diobral demi hasrat duniawi hingga akhirnya religiusitas ikut tergerus dari individuindividu modern.

Yang dikatakan tentu beralasan. Fonemena bisa diamati di tengah majunya peradaban seperti ilmu pengetahuan, tetapi tanpa kebijaksanaan untuk mencegah penyalahgunaan penelitian ilmiah. Teknologi, tetapi tanpa daya spiritual untuk mengantisipasi risiko yang tak terduga yang datang dari teknologi besar dengan efisiensi tinggi. Pesatnya dunia perindustrian tetapi tanpa ekologi untuk memerangi ekonomi yang makin membengkak. Juga gaung demokrasi, tetapi tanpa moralitas yang dapat mengimbangi kepentingan-kepentingan pribadi yang berskala tinggi dari para penguasa secara pribadi atau kelompok.

Fakta-fakta di atas mempertegas hilangnya keseimbangan antara teori dan praktek, antara pikiran dan hati serta antara intelektualitas dan moralitas. Ini problematis sekaligus dilema peradaban. Teknologi dan sains bisa saja punya daya mengubah secara fisikal namun masih cukup lemah untuk membawa transformasi eksistensialis secara holistik. Kemalangan global, sebagaimana dikatakan Bambang Sugiharto, merupakan akibat dari kegagalan proyek modernisme. Kegagalankegagalan itu di antaranya; pertama, pandangan dualistik yang membagi seluruh kenyataan, yakni antara subjek-objek, spiritual-material, manusia-dunia telah mengakibatkan objektivikasi secara berlebihan dan 
penguasaan alam semena-mena, sehingga terjadilah krisis ekologi. Kedua, pandangan modern yang bersifat objektivistik dan positivistik akhirnya cenderung menjadikan manusia seolah-olah objek dan masyarakat pun direkayasa bagaikan mesin. Ketiga, dalam modernisme, ilmu-ilmu positif empiris menjadi standar kebenaran, akibatnya nilai-nilai moral religius kehilangan wibawanya. Keempat, materialisme, apabila kenyataan terdalam tidak didapatkan dalam religi, maka materilah yang dianggap sebagai kenyataan terdalam. Kelima, militerisme, oleh karena normanorma religius dan moral tidak lagi berdaya, maka kekuasaan yang menekan dengan ancaman kekerasan menjadi satu-satunya cara untuk mengatur manusia. Keenam, bangkitnya kembali tribalisme atau mentalitas yang mengunggulkan suku atau kelompok sendiri yang merupakan konsekuensi logis dari hukum survival of the fittest dengan penggunaan kekuasaan yang koersif.

Tak disangkal, perkembangan pesat teknologi memercepat mobilisasi manusia. Namun dalam ranah yang paling intim manusia juga kehilangan sentuhan sosial. Di tahun 2018, sekelompok anak-anak memenuhi jalanan di Hamburg, Jerman untuk melakukan aksi unjuk rasa. Anak-anak ini memprotes para orang tua mereka yang sibuk bermain ponsel ketimbang bermain bersama mereka. Dikutip detik.com dari video DW, Sabtu (15/9/2018), anak-anak tersebut kompak membawa poster yang bertuliskan kata-kata protes mereka. Aksi ini dipimpin oleh Emil Rustige yang baru berusia 7 tahun. ${ }^{9}$

Potret sosial di atas menjadi sangat miris lantaran terjadi di dalam keluarga. Keluarga yang sebetulnya menjadi miniatur dari masyarakat, tempat pertama lahirnya kognisi dan afeksi untuk bersosialisasi, kehilangan sentuhannya. Padahal, seorang pribadi akan menjadi individu sejati jika berada dan berinteksi dengan orang lain. Ia tidak bisa

\footnotetext{
9 "Anak-Anak Jerman Demo di Jalanan Protes Ortu Sibuk Main HP” di dalam Detik.com (Sabtu, 15 September 2018), diakses Selasa 12 Maret 2019,

https://news.detik.com/internasional/d-4213186/anak-anak-jerman-demo-di-jalanan-protesortu-sibuk-main-hp.
} 
menjadi diri sendiri dalam kesendiriannya. Eksistensi hanya akan terjadi jika ada interaksi. Diri yang otentik hanya terbentuk manakala ada korespondensi dengan realitas sosial. Mcmurray mengatakan,

"We need one another to be ourselves. This complete and unlimited dependence of each of us upon the others is the central and crucial fact of personal existence. Individual independence is an illusion; and the independent individual, the isolated self, is a non entity"10.

Yang mau dikatakan Macmurray adalah dependensi merupakan pusat dan fakta krusial penentuan eksistensi diri. Maka dari itu, belajar membangun relasi dan interaksi perlu dihidupi sejak dini. Dalam konteks ini, memulainya dari dan dalam lingkungan keluarga. Mayoritas kita setuju bahwa manusia sekarang berada di zaman yang makin beradab. Tapi kualitas justru kebalikan darinya. Manusia justru dibuat semakin tak beradab. Khamami Zada mengungkapkan bahwa krisis global yang melanda dunia, tidak lain karena semakin merebaknya konflik yang berakibat krisis integrasi sosial. ${ }^{11}$

\section{Komitmen Fundamental yang Tak Terbantahkan}

Dalam upaya menentukan dan menemukan eksistensinya, manusia berproses menuju sebuah totalitas diri, menjadi diri yang otentik. Proses menuju sebuah otentisitas diri tentu akan melewati banyak lingkup dan tahapan. Maka perlu suatu rujukan atau acuan. Otentisitas adalah titik tuju, yang simbolis sekaligus praksis. Namun mengusahakannya perlu komitmen yang (mau tidak mau) menjadi syarat utama. Inilah yang dimaksud oleh Kung. Konsensus ini berangkat dari sebuah kesadaran bersama akan masifnya isu-isu yang dapat membahayakan kehidupan kolektif, yang terejawantah lewat tuntutan fundamental yang tak terbantahkan. Tuntutan-tuntutan itu antara lain:

\footnotetext{
10 John Mill, On Liberty terj. Alex Lanur (Yayasan Obor: Jakarta, 2005), 211.

11 Khamami Zada, Agama, Etika Global dan Perdamaian Dunia (Suara Pembaruan, Rabu 15 Mei 2002).
} 


\section{Non-kekerasan dan Hormat pada Kehidupan}

Kita berbicara perihal dinamika hidup masyarakat global dan lokal. Ada realitas yang tidak bisa dihindari, yang mendarah daging hingga saat ini. Di tengah modernitas kita masih menyaksikan beragam kekerasan fisik dan psikis. Kebencian berseliweran, kecemburuan, iri hati dan kekerasan yang seakan tanpa akhir, tidak hanya antarindividu tetapi juga antara kelompok sosial dan etnik, antarkelas, ras, bangsa, dan agama (kafirmengafirkan, misalnya). Perdagangan obat bius dan kejahatan terorgainsir ${ }^{12}$ demi kepentingan terselubung merajalela. Banyak tempat yang masih dipenuhi oleh teror 'dari atas': diktator yang menindas rakyatnya sendiri, dan berbagai kekerasan institusional dikembangkan ${ }^{13}$. Bahkan irasionalnya, beberapa negara yang punya hukum untuk melindungi kebebasan individu, ternyata tak pernah luput dari kekerasan. Kung mengingatkan kembali dengan merujuk pada petunjuk kuno, janganlah membunuh atau dalam terma positif hormatilah kehidupan. ${ }^{14}$ Ini perlu direnungkan kembali.

Secara hakiki, semua orang mempunyai hak untuk hidup, selamat, dan mengembangkan kepribadian secara bebas sejauh mereka tidak merugikan hak-hak orang lain. Tidak seorang pun mempunyai hak secara fisik ataupun psikis untuk menyiksa, merugikan, atau bahkan membunuh manusia lain. Dan tidak ada orang, negara, ras, atau agama yang mempunyai hak untuk membenci, mendiskriminasi, 'membersihkan', mengasingkan, bahkan menghapuskan minoritas 'orang asing', yang memiliki perilaku dan menyatakan 'kafir' kepercayaan yang berbeda. ${ }^{15}$ Benar bahwa di mana pun manusia hidup pasti ada konflik. Akan tetapi, konflik tidak mesti diselesaikan dengan kekerasan karena muaranya adalah keadilan, baik secara global atau lokal.

\footnotetext{
12 Hans Kung dan Karl-Josef Kuschel, Etika Global, 22.

13 Ibid.

14 Ibid.

15 Hans Kung dan Karl-Josef Kuschel, Etika Global, 23
} 
Mirisnya situasi kini mengundang setiap elemen masyarakat untuk berbenah. Pembekalan pendidikan non-kekerasan mesti ditanamkan sedini mungkin karena pribadi manusia memiliki nilai yang tak terhingga, maka harus selalu dilindungi. Juga, saat berbicara soal manusia maka tak hanya melulu pada relasi antarperorangan melainkan interdependensi terhadap komunitas bumi. Eksploitasi yang tanpa henti terhadap dasar-dasar alami kehidupan, penghancuran yang tidak benar atas biosfer, dan militerisasi kosmos, semuanya adalah kebiadaban.16 Sebagai manusia kita bertanggung jawab (khususnya kepada generasi yang akan datang) mengenai bumi dan kosmos, mengenai udara, air, dan tanah. Kita semua terikat bersama dalam kosmos ini dan kita saling bergantung satu sama lain. Masing-masing kita bergantung pada kesejahteraan semuanya. ${ }^{17}$

Oleh karena itu, dominasi manusia atas alam dan kosmos harus dilarang. Yang dikembangkan adalah harmonisasi dengan alam dan kosmos. Jika intimasi terhadap kosmos dirawat, kesadaran akan dunia tanpa kekerasan dan cinta pada kehidupan akan terus terjalin.

\section{Solidaritas dan Tatanan Ekonomi yang Adil}

Dari perspektif sosial, kecenderungan pergolakan dan benturan antara dunia modern-sekuler dan agama masih terus menghiasi wajah peradaban. Seringkali erat terkait pada masalah ketidakadilan. Meskipun modernitas itu sendiri mengandung kecenderungan-kecenderungan tak adil yang inheren dan struktural dalam dirinya, toh tak seluruh kesalahan mesti ditimpakan kepadanya. Ketidakmampuan manusia sendiri untuk mengintegrasikan kesejahteraan material maupun kecanggihan rasionalitas dan sistem-sistem modern turut melahirkan kepincangankepincangan itu. Muncullah rasa gagal. Degradasi harga diri yang tak jarang melahirkan ilusi yang menghibur. Ilusi bertajuk rasa superior

16 Hans Kung dan Karl-Josef Kuschel, Etika Global, 24.

17 Ibid. 
bahwa manusia adalah istimewa pilihan Tuhan, sementara dunia sekuler-modern adalah setan yang menggoda dan perlu dibasmi. Semacam ada kecenderungan narsistik dalam perspektif Freudian: bila menyangkut hal-hal yang bagus, maka dirinya menganggap itu aslinya dia, tak ada kaitan dengan dunia luar; bila menyangkut hal buruk maka yang buruk adalah dunia luar, dirinya hanyalah akibat dari padanya. Sayangnya narsisisme seringkali juga menunjukkan kekosongan mendasar, perasaan bahwa dirinya sebenarnya bukan apa-apa, nobody, kurang harga diri.

Mentalitas kronis akibat materialistik karena sikap rakus untuk mencari keuntungan yang tanpa batas dan menguras barang jarahan yang tak habis-habisnya menembus elemen dan institusi masyarakat. Kehausan ini menguras dan menguras sumber penghasilan masyarakat tanpa mengharuskan individu untuk lebih memberi kontribusi. Kanker sosial berupa korupsi menjalar cepat di berbagai negara berkembang dan juga negara maju, termasuk Indonesia.

Atas fenomena di atas, penting untuk kembali kepada ungkapan etik kuno, jangan mencuri. Atau dalam terma positif uruslah dengan jujur dan baik. ${ }^{18}$ Konsekuensinya, tidak seorang pun berhak menyerobot atau merebut dengan cara apapun, apa saja milik dan kesejahteraan orang lain dan menggunakan barangnya tanpa memerhatikan keperluan masyarakat dan bumi. ${ }^{19}$

Ketidakjujuran dalam menata ekonomi hanya akan menghasilkan kemiskinan. Akibatnya ketidakpedulian dan keputusasaan berkembang. Pencurian bermunculan demi memertahankan hidup. Di mana kekuasaan dan kekayaan diakumulasi secara tidak benar, di situ perasaan cemburu, kebencian yang mematikan, pemberontakan yang tidak terelakkan akan tumbuh di antara mereka yang tertindas dan

18 Hans Kung dan Karl-Josef Kuschel, Etika Global, 27.

19 Ibid. 
terpinggirkan. ${ }^{20}$ Hal ini akan membawa kepada lingkaran setan kekerasan dan pembalasan. Tepat yang dikatakan Kung, tidak ada perdamaian dunia tanpa keadilan global.

Tata ekonomi seharusnya tidak menimbulkan persaingan yang merusak relasi antarmanusia, dan tidak memperlebar jurang antara si kaya dan si miskin. "Hendaklah kamu sehati sepikir, dalam satu kasih, satu jiwa, satu tujuan, dengan tidak mencari kepentingan sendiri atau puji-pujian yang sia-sia. Sebaliknya hendaklah dengan rendah hati yang seorang menganggap yang lain lebih utama dari pada dirinya sendiri, dan janganlah tiap-tiap orang hanya memerhatikan kepentingannya sendiri, tetapi kepentingan orang lain juga" ${ }^{21}$.

Kung menghimbau, sebuah penyelesaian yang akan dapat didukung oleh semua pihak harus diusahakan untuk mengatasi beban hutang dan kemiskinan yang kian mencekik di negara-negara dunia kedua, lebih-lebih dunia ketiga. Tentu konflik kepentingan tidak bisa dihindari. Di negara-negara maju, harus dibuat pembedaan antara konsumsi wajib dan konsumsi terbatas, antara penggunaan kekayaan yang bermanfaat dan yang tidak bermanfaat secara sosial. ${ }^{22}$

\section{Budaya Toleransi dan Hidup Jujur}

Dalam tradisi agung agama dan etik kuno kita menemukan petunjuk jangan bohong! atau dalam terma positif, bicaralah dan bertindaklah secara benar! ${ }^{23}$ Kita perlu renungkan ini sekali lagi. Konsekuensinya, tidak ada perempuan atau laki-laki, tidak ada institusi, tidak ada negara atau komunitas keagamaan yang berhak berbicara bohong pada manusia lain. Ini tentu saja benar khususnya, bagi orang-orang yang bekerja di media massa dipercayakan kebebasan untuk melaporkan kebenaran. Wajib untuk menghormati martabat dan hak asasi manusia, serta nilai-nilai

\footnotetext{
Ibid.

Filipi 2:1-5.

Hans Kung dan Karl-Josef Kuschel, Etika Global, 29.

23 Hans Kung dan Karl-Josef Kuschel, Etika Global, 32.
} 
fundamental. Penting untuk menegakkan objektivitas, kejujuran, dan pemeliharaan martabat manusia. Tidak ada yang berhak mengganggu wilayah privasi individu, memanipulasi opini publik, atau mendistorsi realitas. ${ }^{24}$ Konteks Indonesia sangat rentan. Terjadi gap yang cukup signifikan. Terjadi pembalikan realitas sosial antara usaha untuk mewujudkan petunjuk jangan bohong terhadap kenyataan di masyarakat. Berita hoaks menyebar menembus batas, tingkatan umur, institusi dan lapisan masyarakat, melalui jejaring sosial: internet, surat kabar dan alat komukasi lainnya dalam segala varian kuantitas. Lahir kelompok sosial tukang kepo privasi hidup orang lain (netizen). Berkaitan dengan fenomena kebohongan publik ini bahkan, dalam sebuah kesempatan, dikatakan oleh Presiden Joko Widodo. "Dalam memerangi hoaks, dibutuhkan upaya dari semua pihak untuk membangun budaya baru, terutama budaya kesantunan dan kesopanan dalam berujar di media sosial. Jangan menghasut, jangan memfitnah, jangan menyebarkan kabar bohong, jangan menyebarkan ujaran kebencian". ${ }^{25}$ Dalam konteks hidup beragama, muncul prasangka, kebencian, dan permusuhan terhadap kepercayaan lain, atau bahkan menghasut melegitimasi perang dingin agama. ${ }^{26}$ Tidak ada keadilan global tanpa rasa saling percaya dan kemanusiaan, kata Kung. Ibaratnya, setiap orang perlu belajar menjadi manusia terlebih dahulu sebelum mendalami agamanya supaya suatu saat ketika orang membela agamanya, orang tidak menjadi Tuhan bagi orang lain. Semua orang harus mampu menanamkan sikap percaya bagi sesamanya karena memanipulasi kebenaran atau tidak jujur dalam beragam ruang persoalan, manusia sebetulnya kehilangan kredibilitas yang melekat pada unsur otentiknya sebagai citra Allah.

\footnotetext{
24 Ibid.

25 "Jokowi Tanggapi Keluhan Soal Hoax di Media Sosial" dalam CNNIndonesia.com (Minggu, 22 Januari 2017), diakses Selasa, 12 Maret 2019, https:/www.cnnindonesia.com/nasional/20170122151245-32-188064/jokowi-tanggapikeluhan-soal-hoax-di-media-sosial.

26 Hans Kung dan Karl-Josef Kuschel, Etika Global, 33.
} 
Kebermasyarakatan yang jujur membutuhkan sikap menghargai dari semua unsur lapisan masyarakat. Dalam pengertian ini, menanamkan sikap toleransi menjadi suatu keharusan demi kehidupan yang damai. Halim dalam artikel yang berjudul Menggali Oase Toleransi, menyatakan "Toleransi berasal dari bahasa latin, yaitu tolerantia, berarti kelonggaran, kelembutan hati, keringanan dan kesabaran"27. Secara umum istilah ini mengacu pada sikap terbuka, lapang dada, suka rela, dan kelembutan. Untuk itu toleransi harus didukung oleh cakrawala pengetahuan yang luas, bersikap terbuka, dialog, kebebasan berpikir dan beragama. Singkatnya toleransi setara dengan sikap positif dan menghargai orang lain dalam rangka menggunakan kebebasan asasi sebagai manusia. Hakikat toleransi adalah hidup berdampingan secara damai dan saling menghargai di antara keragaman. Di Indonesia, praktek toleransi mengalami pasang surut. Pasang surut ini dipicu oleh pemahaman distingtif yang bertumpu pada relasi "mereka" dan "kita". Tak pelak, dalam berbagai kontemporer, sering dikemukakan bahwa, radikalisme, ekstremisme, dan fundamentalisme merupakan baju kekerasan yang ditimbulkan oleh pola pemahaman yang eksklusif dan antidialog atas teks-teks keagamaan.

Untuk membangun toleransi sebagai nilai kebijakan setidaknya ada dua modal yang dibutuhkan yaitu: Pertama, toleransi membutuhkan interaksi sosial melalui percakapan dan pergaulan yang intensif. Kedua, membangun kepercayaan di antara berbagai kelompok dan aliran. Prinsip dasar semua agama adalah toleransi, karena semua agama pada dasarnya mencintai perdamaian dan antikekerasan. ${ }^{28}$

Maka sangat urgen bagi Kung bahwa di tengah banjir informasi setiap hari, standar etik akan membantu mereka melihat ketika opini

\footnotetext{
27 Abdul Halim, "Menggali Oase Toleransi" dalam Kompas.com (14 April 2008) diakses Rabu, 20 Maret 2019,

http://www.kompas.com/kompascetak/read.php?cnt=.xml.2008.04.14.02192027\&channel=2\& $\mathrm{mn}=174 \& \mathrm{id} x=174$.

28 Daniel L. Smith (editor), Lebih Tajam dari Pedang-Refleksi Agama-agama Tentang Paradoks Kekerasan (Yogyakarta: Kanisius, 2005).
} 
dihadirkan sebagai fakta, kepentingan yang terselubung, tendensitendensi yang dilebih-lebihkan, dan fakta-fakta yang diputarbalikkan.

\section{Kesejajaran Hak dan Kerja Sama}

Seluruh manusia berjuang menjalani kehidupan dalam semangat kerja sama dan tindakan yang bertanggung jawab dalam hal cinta, seksualitas, dan keluarga. Meski demikian, di seluruh dunia juga masih ada berbagai praktik terkutuk seperti patriarkhi, dominasi satu jenis kelamin atas yang lainnya, eksploitasi perempuan, pelanggaran seksual atas anak-anak, dan prostitusi yang dipaksa. Tak jarang, ketidaksejajaran sosial menjerumuskan perempuan dan bahkan anak-anak ke dalam prostitusi sebagai sarana memertahankan hidup -khususnya di negara-negara yang kurang maju.

Hormatilah dan cintailah satu sama lain!29. Kita mesti kembali merefleksikan ungkapan di atas. Tidak seorang pun berhak merendahkan orang lain semata-mata sebagai obyek dalam situasi apa pun dan kondisi mana pun. Satu bentuk kemerosotan manusia paling buruk adalah dominasi satu terhadap yang lain secara fisik maupun psikis. Tidak akan pernah terwujud kemanusiaan otentik tanpa hidup bersama dalam kerja sama! Relasi antara laki-laki dan perempuan mesti bersifat kreatif dan afirmatif. ${ }^{30}$ Hubungan laki-laki dan perempuan seharusnya tidak bersifat patronasi atau eksploitasi, tetapi dengan cinta, kerja sama, dan saling memercayai. Bahkan sejak awal Allah bermaksud agar manusia menikmati persekutuan dengan sesamanya: "Tidak baik kalau manusia itu seorang diri saja. Aku akan menjadikan penolong baginya, yang sepadan dengan dia." (Kejadian 2:18). Masyarakat sejati adalah masyarakat yang diwarnai oleh persekutuan. Juga, pemenuhan manusia tidak identik dengan kenikmatan seksual. Seksualitas seharusnya merupakan ekspresi dan memperkuat hubungan cinta,

29 Hans Kung dan Karl-Josef Kuschel, Etika Global, 36.

30 Hans Kung dan Karl-Josef Kuschel, Etika Global, 37. 
secara sejajar. ${ }^{31}$

Institusi pernikahan (laki-laki dan perempuan) misalnya, walaupun bervariasi secara kultural dan keagamaan, dicirikan oleh cinta kesetiaan, dan kelanggengan. Ia bertujuan dan harus menjamin keamanan dan saling mendorong antara suami, istri, dan anak-anak. ${ }^{32}$ Ia harus menjaga hak semua anggota keluarga. Semua negara dan budaya harus mengembangkan hubungan ekonomi dan sosial yang akan memungkinkan tumbuhnya perkawinan dan kehidupan keluarga yang layak bagi manusia, khususnya untuk orang-orang tua. Anak-anak mempunyai hak memeroleh pendidikan. Bagi Kung, menjadi manusia otentik hanya bisa dimungkinkan dengan sikap saling menghormati, kerja sama dan pemahaman, bukannya dominasi dan kemerosotan patriarkat, yang merupakan bentuk kekerasan dan akan memancing pembalasan. Hanya apa yang sudah dialami dalam hubungan personal dan keluarga yang bisa dipraktikkan pada tingkat bangsa-bangsa dan agama-agama. Namun prinsip-prinsip di atas tidak akan mampu membumi dan terwujud, jika tidak dilakukan upaya transformasi kesadaran individu maupun publik. Kemungkinan bagi transformasi terdapat dalam wilayah seperti perang dan perdamaian, ekonomi dan ekologi, di mana dalam dekade terakhir telah terjadi beberapa perubahan fundamental. ${ }^{33}$ Transformasi ini juga harus dilakukan dalam wilayah etik dan nilai-nilai. ${ }^{34}$

\section{Membingkai Komitmen dan Realitas}

Manusia itu makhluk yang relasional, dengan relasi tiga ganda, yaitu: relasi dengan Allah, relasi dengan sesamanya dan relasi dengan alam semesta. Memertahankan relasi ini merupakan keharusan demi terwujudnya tujuan manusia sendiri yakni menjadi makhluk otentik.

\footnotetext{
Ibid.

Hans Kung dan Karl-Josef Kuschel, Etika Global, 38.

Hans Kung dan Karl-Josef Kuschel, Etika Global, 39.

34 Ibid.
} 
Keharusan ini merupakan panggilan hidup setiap orang di mana pun di tengah realitas kehidupan yang berbeda-beda, bagi seluruh bangsa, dalam kultur yang berbeda-beda dan tradisi agama yang berbeda-beda. Namun upaya dan kerja keras tidak akan menjadi mustahil jika dikoherensikan dengan komitmen nyata. Bahwa perbedaan perspektif masing-masing, akan menemukan titik temu setidaknya dibingkai sebagai implementasi khususnya menarik benang merah antara gagasangagasan Kung untuk diaplikasikan ke dalam pluralitas bangsa-bangsa di dunia. Ini berarti, setiap bangsa berhak merumuskan realitas sosial dan konstitusi negaranya dengan mengambil saripati pemikiran Kung sebagai norma bersama. Pun dalam konteks masyarakat Indonesia, gagasan Kung akan sejalan dengan cita-cita bangsa Indonesia jika dibaca ulang dengan penuh kesadaran dalam terang semangat Pancasila. Pancasila yang notabene merupakan norma dasar negara bisa berdiri kokoh manakala dijalankan dengan mengusahakan koherensi antarsila, konsistensi dengan produk-produk perundangan, dan korespondensi dengan realitas sosial. Ketuhanan.

Perpaduan komitmen fundamental Kung dan semangat Pancasila untuk mewujudkan manusia Indonesia yang lebih otentik dibingkai ke dalam tiga unsur yaitu unitarisme, demokrasi permusyawaratan dan sosialisme.

\section{Unitarisme}

Prinsip unitarisme dipandang lebih sejalan dengan pokok pikiran pertama Pembukaan UUD 1945, "Negara"-begitu bunyinya-yang melindungi segenap bangsa Indonesia dan seluruh tumpah darah Indonesia dengan berdasarkan atas persatuan dengan mewujudkan keadilan sosial bagi seluruh rakyat Indonesia. Bahkan dalam konsep pemikiran Driyarkara (barangkali tafsir atas pemikiran Aristoteles) bahwa negara sebagai tempat perwujudan ultima makhluk bernama manusia. Hanya dalam negaralah manusia menemukan perwujudannya sebagai makhluk berakal budi, yang memiliki hakikat sosial dan sebagai 
makhluk yang dipanggil ke kesucian (mendekat pada Tuhan). ${ }^{35}$ Timbul kehendak mewujudkan negara persatuan yang dapat mengatasi perbedaan paham perseorangan dan golongan. Negara menurut pengertian ini menghendaki persatuan, meliputi segenap bangsa Indonesia seluruhnya. Bentuk negara yang oleh sebagian besar pendiri bangsa dipercaya bisa menjamin persatuan integralistik yang kuat bagi negara kepulauan Indonesia adalah negara kesatuan (unitary).

Pengalaman traumatis politik devide et impera dan pembentukan negara federal yang dikembangkan oleh kolonial memerkuat keyakinan bahwa hanya dalam persatuan yang bulat-mutlak, yang mengesampingkan perbedaan, yang membuat Indonesia bisa meraih dan memertahankan kemerdekaan. Semangat persatuan yang bulat-mutlak itu dirasa lebih cocok diwadahi dalam bentuk negara kesatuan. Meski demikian, para pendiri bangsa menyadari benar, bahwa penerapan bentuk negara kesatuan tersebut haruslah koheren dengan watak kemajemukan bangsa Indonesia. Oleh karenanya, negara kesatuan itu haruslah memberi ruang gotong royong (pelibatan aspirasi dan partisipasi daerah) dalam pengelolaan negara melalui asas desentralisasi dan dekonsentrasi.

Prinsip unitarisme yang membawa unsur penting, keadilan dan gotong royong, sejalan dengan pemikiran Kung tentang solidaritas dan tatanan ekonomi yang adil. Solidaritas selalu mengandaikan gotong royong (bersama-sama) demi rasa adil dalam hidup berbangsa dan bertanah air. Orang bisa menjadi solid satu sama yang lain jika ada keadilan. Orang merasa sehati dan sejiwa sebagai bagian dari bangsa Indonesia apabila diperlakukan dengan adil. Karena itu, sulit menghidupi perasaan sepenanggungan jika ketidakadilan masih merebak di mana-mana. Yang terjadi adalah pengotak-ngotakan dalam

\footnotetext{
35 A. Setyo Wibowo, Negara-Pancasila Menurut Driyarkara: Melacak Asal-usul dan Artinya dalam F. Wawan Setyadi (editor) Meluhurkan Kemanusiaan (Jakarta: Penerbit Buku Kompas, 2018), 141.
} 
berbagai elemen. Rasa solid akan terasa jauh untuk digapai.

\section{Demokrasi Permusyawaratan}

Prinsip demokrasi permusyawaratan dipandang sejalan dengan pokok pikiran ketiga Pembukaan UUD 1945, "negara yang berkedaulatan rakyat, berdasar atas kerakyatan dan permusyawaratan perwakilan". Demokrasi Pancasila mengandung prinsip-prinsip fundamental yang tersusun dalam kerangka etis cita kerakyatan, cita permusyawaratan, dan cita hikmat-kebijaksanaan. Cita kerakyatan hendak menghormati suara rakyat dalam politik; dengan memberi jalan bagi peranan dan pengaruh besar yang dimainkan oleh rakyat dalam proses pengambilan keputusan yang dilakukan oleh pemerintahan negara.

Cita permusyawaratan hendak menghadirkan negara persatuan yang dapat mengatasi paham perseorangan dan golongan, sebagai pantulan dari semangat kekeluargaan dari pluralitas kebangsaan Indonesia dengan mengakui adanya "kesederajatan/persamaan dalam perbedaan". Gagasan persatuan nasional awal bisa dilihat dari pemikiran Tjiptomangunkusumo yang menginginkan terciptanya "kesatuan dalam perbedaan", sebuah masyarakat yang hidup bersama dalam keselarasan, menghormati satu sama lain sebagai orang yang sama-sama sederajat. ${ }^{36}$

Dengan kata lain, manusia Indonesia diajak untuk merawat prinsip kesederajatan hak. Bahwa ada pluralitas yang menjadi wajah kita namun di dalamnya ada persamaan yaitu hak untuk hidup, hak untuk berserikat dan berpendapat dan hak memeluk suatu agama. Dalam konsep Kung, perlu dikembangkan komitmen kesejajaran hak dan kerja sama. Menyadari bahwa dalam perbedaan kita butuh kerja sama untuk menjaga kesejajaran hak sebagai bagian dari masyarakat Indonesia.

Cita hikmat-kebijaksanaan merefleksikan orientasi etis, berlandaskan nilai ketuhanan, perikemanusiaan, persatuan, permusyawaratan dan

\footnotetext{
36 Savitri Scherer, Keselarasan dan Kejanggalan: Pemikiran-Pemikiran Nasionalis Priyayi Jawa
} Awal Abad XX (Jakarta: Sinar Harapan, 1985), 151. 
keadilan. Maka hormat pada kehidupan dan budaya non-kekerasaan (pemahaman Kung) adalah realisasi paling agung dari nilai ketuhanan dan perikemanusiaan. Ketuhanan Yang Maha Esa menjadi dasar yang memimpin sila-sila lain, dasar spiritual dan etik, yang memberi negara landasan moral yang kukuh. ${ }^{37}$

Hal ini mengandung konsekuensi seperti yang dikemukakan oleh Mohammad Hatta, bahwa "Kerakyatan yang dianut oleh bangsa Indonesia bukanlah kerakyatan yang mencari suara terbanyak saja, tetapi kerakyatan yang dipimpin oleh hikmat kebijaksanaan dalam permusyawaratan perwakilan." Selanjutnya dikatakan, "Karena itu demokrasi Indonesia bukan demokrasi liberal dan juga bukan demokrasi totaliter, karena berkaitan secara menyeluruh dengan sila-sila Pancasila lainnya". Menurut Beetham dan Boyle, demokrasi mengisyaratkan kebhinekaan dan kemajemukan dalam masyarakat maupun kesamaan kedudukan di antara para warga negara. ${ }^{38}$

\section{Sosialisme}

Prinsip sosialisme dipandang sejalan dengan pokok pikiran kedua Pembukaan UUD 1945, "Negara hendak mewujudkan keadilan sosial bagi seluruh rakyat Indonesia." Seluruh kekuatan trilogi ideologi bersepakat bahwa sumber kesengsaraan dan kemelaratan bangsa Indonesia di masa kolonial adalah kapitalisme dan imperialisme. Adapun kapitalisme dan imperialisme dipandang sebagai anak kandung dari individualisme. Individualisme itu penghalang cita-cita hidup bersama. Perasaan "kita" dan "mereka" tetap hadir dalam wajah plural Indonesia jika yang dipupuk adalah individualisme karena pasti menjadi lahan subur radikalisme, ekstremisme, dan fundamentalisme.

\footnotetext{
37 Ahmad Syafii Maarif, Islam dan Pancasila Sebagai Dasar Negara: Studi Tentang Perdebatan Dalam Konstituante (Jakarta: LP3ES, 2006), 157-9.

38 David Beetham dan Kevin Boyle, Demokrasi: 80 Tanya Jawab, terj. Bern Hidayat (Yogyakarta: Kanisius, 2000), 23.
} 
Menjadi sosialis adalah mampu sadar dan merasa bahwa masyarakat hidup berdampingan dan butuh berdampingan karena simpulnya ada pada penghargaan terhadap keragaman kita. Toleransi ala Kung penting untuk dimasukkan dalam ranah ini. Sebab dengan berkembangnya toleransi, maka terjalinnya hubungan antaranggota dari berbagai kelompok, hal ini dapat menetralisir terjadinya konflik-konflik sosial dan tidak khawatir akan terjadi fanatisme sempit serta sentimensentimen yang bersifat primordial. Di samping itu, interaksi yang dilakukan dalam kehidupan bersama mengacu kepada nilai-nilai umum yang dijunjung oleh semua warga masyarakat plural/majemuk

Jawaban atas persoalan ini memerlukan antitesis dalam bentuk sosialisme. Dalam perkembangannya, berbagai usaha konsepsional dilakukan untuk membumikan sosialisme dalam kenyataan sosialhistoris negeri ini, yang kemudian melahirkan apa yang disebut sebagai sosialisme ala Indonesia. Sebutan Bung Karno atas sosialisme ala Indonesia ini adalah Marhaenisme. Menurut sosialisme Indonesia, hak milik pribadi itu boleh, tapi hak milik itu memiliki fungsi sosial yang harus digunakan sesuai dengan sifat-sifat sosial dari hak milik tersebut. Fungsi sosial dari hak milik itu adalah primer, dalam arti bahwa hak milik tidak boleh dipergunakan (atau dibiarkan) merugikan masyarakat.

\section{Kesimpulan}

Adalah sebuah pertaruhan memerjuangkan usaha memanusiakan manusia di tengah derasnya arus globalisasi yang memberi banyak dampak positif dalam mobilisasi interaksi masyarakat sekaligus melahirkan isme-isme yang mencemaskan hajat hidup orang banyak. Namun kita boleh belajar dari Hans Kung dengan konsep-konsepnya yang sebetulnya bukan hal baru bagi kita. Konsep sederhana yang sering diabaikan. Setiap orang bisa menarik saripati pesan dari petunjuk kuno yang digagas Kung untuk diaplikasikan ke dalam tatanan global dan lokal. Secara khusus, dalam tatanan lokal, kehidupan berbangsa dan bertanah air Indonesia, Kung menyajikan perspektif dan argumen yang 
bisa direfleksikan secara bersama-sama agar kita mampu hidup sehati dan sejiwa di bawah semangat Pancasila.

Mengapa semangat Pancasila? Di dalam era ketidaklogisan komunikasi, kehidupan sosial yang terfragmentasi, pragmatisme terhadap konsistensi, penting untuk mengembalikan Pancasila agar dihayati, dipahami dan diaplikasikan dalam kehidupan bernegara. Yudi Latif dalam bukunya menggunakan konsep dari sejarawan Kuntowijoyo, Radikasilasi Pancasila mengatakan bahwa menjadi keharusan mengembalikan Pancasila kepada jalur ideologisnya sebagai ideologi negara dan juga diilmiahkan seperti ilmu. Pancasila juga harus berdialog dengan realitas sosial, menjadi kritik terhadap kebijakan negara serta mengubah paradigma dari melayani kepentingan vertikal (negara) menjadi melayani kepentingan horizontal. ${ }^{39}$

Dengan demikian, belajar dari Kung untuk konteks Indonesia kita bisa merenungkan unitarisme dengan menghidupkan dimensi solidaritas dan adil meskipun kita adalah bangsa yang plural. Dalam semangat demokrasi permusyawaratan kita korespondensikan dengan menyuburkan budaya non-kekerasan dan hormat pada kehidupan. Sementara untuk menjadi lebih sosialis kita bisa membingkainya dalam perwujudan toleransi di tengah kemajemukan bangsa kita. Koherensi antara belajar perspektif Kung dan semangat Pancasila akan bersimpuh pada trilogi kearifan bangsa: silih asah, silih asih dan silih asuh. Tidak mudah untuk belajar, tetapi mesti sadar untuk belajar dan berefleksi karena semuanya untuk kita, untuk menjadi bangsa yang bersahaja, manusia-manusia Indonesia yang otentik.

\footnotetext{
39 Yudi Latif, Negara Paripurna: Historisitas, Rasionalitas dan Aktualisasi Pancasila (Jakarta: Gramedia, 2011), 48.
} 